\author{
小，中学生の先天性心疾患患児の疾患理解 \\ 一患児の「年齢」と疾患の「重症度」による疾患理解の比較— \\ 久保 瑶子 ${ }^{1)}$, 中島 弘道 $^{2)}$, 中澤 潤 $^{3)}$ \\ 1) 東京学芸大学大学院連合学校教育学研究科・博士課程 \\ 2) 千葉県こども病院循環器科 \\ 3) 千葉大学・教育学部
}

\title{
Disease Understanding in Primary and Junior High School-Aged Children with Congenital Heart Disease according to Age and Severity
}

\author{
Yoko Kubo ${ }^{1)}$, Hiromichi Nakajima ${ }^{2)}$, and Jun Nakazawa ${ }^{3)}$ \\ 1) Doctor Course, The United Graduate School of Education, Tokyo Gakugei University \\ 2) Department of Cardiology, Chiba Children's Hospital \\ 3) Faculty of Education, Chiba University
}

Background: For the transition to adult health care, it is important that children with congenital heart disease (CHD) understand their disease. However, disease understanding in children has not been well documented. This study evaluated the ability of children with CHD to understand their disease according to patient age and disease severity.

Methods: A total of 28 children in grades 1-9 who received treatment at a pediatric cardiology department participated in semi-structured interviews.

Results: No differences according to age or severity were observed in children's knowledge of "limitation of exercise," "medication frequency," "medication effect," and "prevention of infective endocarditis." However, understanding of "disease name," "medication name," "reason for consultation," "next consultation date," and "self-management of medication" increased with age. "Cardiac defect" was specifically understood best by patients with mild symptoms.

Conclusion: The results suggest that care providers should explain the disease to children with CHD while considering cognitive development and disease complexity.

背景 : 成人科への移行に向けて, 幼い頃から患児本人が疾患を理解することは重要であるが, 患児の疾患理 解についてはよく検討されていない. 患児の「年齢」や疾患の「重症度」による疾患理解の特徴を比較した.

方法 : A 県内の小児専門病院循環器科に通院中の小学 1 年生から中学 3 年生の先天性心疾患患児 28 名を 対象に, 半構造化面接を行った.

結果 : 運動制限, 薬の頻度・効果, 感染性心内膜炎の予防の理解は, 患児の「年齢」や疾患の「重症度」 による差が見られなかった. しかし, 病名, 薬の名称, 受診の理由, 次回の受診日の理解では, 患児の「年 齢」による差が見られ, 年齢が上がると共に, 理解している患児が増加し, 薬の管理の主体は「親」から「患 児」へと移行していた。 心蔵の久陥の理解では, 疾患の「重症度」による差が見られ, 軽度の患児の方が具 体的に理解していた。

結論 : 医療者は, 患児に疾患説明を行う際, 認知的な発達段階や疾患の構造の複雑さを考慮して説明を行 うことが重要である.

Keywords: cognitive development, disease understanding, transition preparation

2014 年 10 月 20 日受付, 2015 年 2 月 11 日受理

別刷り請求先 : =263-8522 千葉県千葉市稲毛区弥生町 1-33 千葉大学教育学部 久保瑶子 (中澤 潤研究室)

doi: $10.9794 /$ jspccs. 31.52

(C) 2015 Japanese Society of Pediatric Cardiology and Cardiac Surgery 


\section{背景と目的}

医療の進歩に伴い，現在では $90 \%$ 以上の先天性心 疾患患児（以下，患児）が成人を迎える ${ }^{1)}$. 成人期の 患者は, 小児期とは医学的に抱えている問題が異な る ${ }^{2)}$ ため, 患児は 18 歳頃までに小児科から成人科へ と移行することが望まれる. 小児科から成人科への移 行を成功させるためには，小児科の頃から，患児が自 分の疾患を理解し，セルフケアを行えるように，移行 準備をする必要がある.

小児科から成人科への移行は, 患児にとって心理的 な負担が大きい, 子ども病院と循環器内科のある病院 が距離的に遠いなどの問題から困難さが残る。しかし 実際には, 患児のドロップアウトは, 小児科から成人 科への移行段階よりも, 小児科の間によく起こる問題 である ${ }^{3)}$.これは親の疾患理解のそしさ ${ }^{4)}$ が主な原 因であろう．親から疾患管理を任されている患児は， 自分の病状について良く理解しており, 成人科への移 行について良く説明ができ, 親から自立して疾患管理 を行うことができる ${ }^{5)}$ と言われており，患児が幼い 頃から, 自分の病状や定期的に受診する必要性を理解 することは重要である.

これまで，青年期や成人期の患者の疾患理解を明ら かにした研究 ${ }^{6-8)}$ では, 青年期や成人期の患者であっ ても，医学的な内容を理解することの困難さが示唆さ れており，青年期前の患児が疾患について理解する ことは，なおさら困難であることが予想される。し かし, 親元を離れて学校で生活する児童期以降の患 児は，自分でセルフケアを行うために，疾患について 理解する必要がある．また小览科の医師が，移行準備 として，患児に疾患説明を行うにあたり，移行期前の 患児の疾患理解の程度を明らかにすることは重要であ る. しかし，これまで览童期や思春期の患児の疾患理 解に焦点を当てた研究はわずかしかない。伊庭 ${ }^{9)}$ は, 幼児や小学校低学年の患児は, 自分が心蔵病であるこ とや手術の経験，薬の服用，日常生活における制限に ついて理解していることを明らかにした．また，小学 校中学年以降になると，疾患の原因，疾患を抱える自 分の将来，友人との違いについても考え始めること を明らかにした。 また，仁尾・藤原 ${ }^{10)}$ は，11 歳から 15 歳の患児は, 病気の受容をめぐって葛藤し, 社会 的な疎外と限界に困難を感じながらも，病気のコント ロールと自立に向けて挑戦していることを明らかにし た.

これらの研究から，患児の疾患の捉え方や受け止め 方など広い意味での疾患理解は明らかになった。しか
し，医師が患児に疾患説明を行う際の手がかりとし て, 患児が心臓の欠陥, 病名, 運動制限, 薬, 感染性 心内膜炎の予防，受診の理由，次回の受診日につい て, どの程度理解しているのかを把握することは重要 である. そこで本研究では，小，中学生の患児が上記 の内容についてどの程度理解しているのかを明らかに する.

患児の疾患理解には, 認知的な発達が影響してい る. 患児は，日常的に身体活動に伴う疲労や薬の服用 を経験しており，特別な状況でなくても心疾患であ

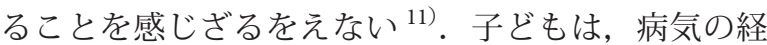
験を通して，その臓器について知るようになる ${ }^{12)} た$ め, 患児も心疾患という独自の経験によって, 幼い頃 から心蔵を知っている．それに加えて，我が国の学校 の理科では，小学 6 年生で心臓の名称，位置，はたら き, 中学 2 年生で心臓のつくり, 血液の循環, 「心室」 や「弁」などの解剖用語を学習する。児童期や思春期 の患児は，心臓の基礎的な知識を身につけており，疾 患を理解する上でのレディネス (準備性) はすでに 整っている。

小学 1 年生になると，具体的な経験や対象，事象に ついて, 論理的な思考が可能になり, 情報を整理・分 類・順序立てて考えることが可能になる具体的操作段 階に入る $\left.{ }^{13}, 14\right)$. この時期は, 言葉を通しての抽象的 なことよりも，見たり聞いたり経験したことを全体と して記憶する傾向があるため ${ }^{9,14)}$ ，患児が日常的に経 験している身体の疲労などから疾患を認識する。

小学 4 年生になると, 直接体験していなくても, 説明や本などの間接経験を通して学習することができ たり，語の意味（概念）を定義したり，知識を階層的 に体系づけたりすることができるようになる ${ }^{15)}$. ま た，9歳頃から始まる急激な認知機能の発達と，学校 生活で同年齢の子どもとの関わりが増えるため, 友人 との社会的比較により，自分の能力や行動を自己評価 するようになる ${ }^{16)}$ 。この時期の患児は，医療者や親 からの説明や本を通した疾患理解が可能になるため, 疾患理解の幅が広がるだろう。また，情報を体系づけ て考えられるようになるため, 病状と受診の理由な どを関連づけて考えることができる。そして，友人 と自分を比較する ${ }^{16)}$ ことによって，疾患を抱える自 分が友人と同じようにできないことに嫌悪感を抱くよ うになるため，運動制限のある患児の中には，疲労を 感じていても無理して運動を続けてしまう者も出てく $ろ^{9)}$.

中学 1 年生になると, 具体的事象にとらわれずに, 抽象的思考が可能となる形式的操作段階 ${ }^{13)}$ に入り, 
具体的操作期までに得た論理的関係について, 仮説を 立て，推論することができるようになる ${ }^{17)}$.また, 第二次性徴として, 身体が劇的に発達するため, 変化 する自分の身体や内面に関心が向けられる ${ }^{18)}$ ．この 時期の患児は，これまでに得た疾患に関する知識の関 係性を基に推論しながら, 先を見通して疾患と付き合 うことを考えられるようになる。 また, 保護された生 活からの自立を模索し, 自分の身体を自分で守ろうと する傾向が強まる ${ }^{10)}$. そのため, これまで親が主体 となって行われていたセルフケアは, この時期を境に 患児が主体となって行うようになることが望ましい。 以上の認知的な発達段階を踏まえて, 本研究では, 患 児の「年齢」を小学校低学年, 小学校高学年, 中学生 に分けて, 疾患理解の特徵を比較する.

また, 疾患の重症度によっても, 疾患理解には差 が見られる. Moons ${ }^{19)}$ らは, ファロー四徵症の患者 は, 大動脈狭窄症や大動脈弁狭窄症の患者よりも, 図 表に心蔵の欠陥を正確に位置づけることができないこ とを示し, 心臟の久陥を描くことが困難な複雑な心疾 患の患者の方が疾患理解がそしいことを示唆した。一 方で, ファロー四徵症や大血管転位症を含むチアノー ゼがある患児の親は, チアノーゼがない患児の親より も病名をよく理解しており ${ }^{4)}$, 重症な心疾患の患児の 親の方が疾患理解が良いことを示した。 これらの結果 から, 患者と親では, 疾患の重症度が疾患理解に与え る影響は逆であるものの, 疾患理解は疾患の重症度 に影響を受けることが同える，そこで本研究では, 疾患の重症度による疾患理解の特徴を比較するため に, Adult Congenital Heart Association ${ }^{20)}$ を参考に, 疾患の「重症度」を軽度, 中等度 (本論では, Great Complexity と Moderate を合わせて, 中等度とする） に分ける. 小, 中学生を対象にした本論において,

Adult Congenital Heart Association ${ }^{20)}$ を参考にした のは, 先天性心疾患は生涯を通して付き合う疾患であ り, 基本的には幼少期から成人期まで疾患の重症度は 変化しないと考えたためである.

以上を踏まえて, 本研究では, 小, 中学生の先天性 心疾患患児の疾患理解に焦点を当て, 患児の「年齢」 や疾患の「重症度」によって, 疾患理解に特徴がある のかを比較する. そして, 医療者が小, 中学生の患児 に疾患説明を行う際の手がかりへの示唆を得ることを 目的とする.

\section{方法}

用語の定義 先天性心疾患 : 生まれつきの心奇形だけ
でなく，不整脈も含める.

疾患理解：患児が病状やセルフケアについて正しく理 解していること.

調査協力者 $\mathrm{A}$ 県内の小児専門病院循環器科に通院 中の小, 中学生の先天性心疾患患児 28 名. 事前に調 査に関する説明を聞くことを承諾した 56 名のうち, 遺伝子異常, 発達障害, 難聴など言語によるコミュニ ケーションの困難さを抱えておらず，さらに外来の予 約時間が重なっていない 28 名を選定した. 疾患理解 の特徴を比較するために, 患児の「年齢」を小学校 低学年 8 名（男児 6 名, 女児 2 名, $M=7.81$ 歳, $R=$ $6: 3 \sim 9: 1$ ), 小学校高学年 6 名 (男児 3 名, 女児 3 名, $M=10.85$ 歳, $R=9: 5 \sim 11: 10$ ), 中学生 14 名 (男児 7 名, 女児 7 名, $M=13.71$ 歳, $R=12: 4 \sim 15: 3 ）$ に分 けた。.また, 疾患の「重症度」を軽度 15 名（小学校 低学年 3 名, 小学校高学年 3 名, 中学生 9 名, $M=$ 11.82 歳), 中等度 13 名 (小学校低学年 5 名, 小学校 高学年 3 名, 中学生 5 名, $M=10.94$ 歳) に分けた. 患児の疾患名は, Table 1 に示す。薬を服用している 患児 (全て中等度) は, 小学校低学年で 3 名, 小学校 高学年で 1 名, 中学生で 2 名いた.

調査時期 2013 年 8 月 13 日 2013 年 8 月 30 日.

調査方法 個別に半構造化面接を行った. 面接は発達 心理学を専門とする調査者 1 名が行った。面接時間は 一人あたり $3 \sim 16$ 分, 平均時間は 8.00 分 $(S D=2.67)$ であった. 調査協力者の回答は, 許可を得て ICレ コーダーで録音すると共に調査者が筆記した。

患児が希望する場合は，親が面接に立ち会った（28 名中 11 名). その場合は，面接前に親に対して患児 の面接が終了するまで発言を控えるように頼んだ.

調査内容 質問は計 10 項目であった。質問内容は, 「病状」として(1)自分がどんな病気か知っているか (心

Table 1 Diagnosis $(n=28)$

\begin{tabular}{lll}
\hline Severity & \multicolumn{1}{c}{ Diagnosis } & $\mathrm{n}$ \\
\hline \multirow{3}{*}{ Simple } & Ventricular septal defect & 6 \\
& Atrial septal defect & 6 \\
& Mitral regurgitation & 1 \\
& Patent ductus arteriosus & 1 \\
& Coronary artery fistula & 1 \\
\hline \multirow{3}{*}{ Moderate } & Tetralogy of Fallot & 2 \\
& Total anomalous pulmonary venous drainage & 1 \\
& Aortic insufficiency & 1 \\
& Congenital pulmonary arteriovenous fistula & 1 \\
& Aortic stenosis & 1 \\
& Pulmonary atresia & 1 \\
& Single ventricle & 3 \\
& Complete atrioventricular block & 3 \\
\hline
\end{tabular}


臓の欠陷) (2)病気の名前は知っているか（病名),「セ ルフケア」として(3)体育の時に気をつけていることは あるか (運動制限)，(4)薬は誰が持ってくるか (薬の 管理の主体)，(5いつ薬を飲んでいるか(薬の頻度), (6)どんな薬を飲んでいるか (薬の効果), (7)薬の名前 は知っているか (薬の名称)，8穴臓のために歯のこ とで気をつけていることはあるか（感染性心内膜炎の 予防)，(9)日こども病院に来た理由を知っているか (受診の理由), (10次はいつこども病院に来るのか（次 回の受診日）を尋ねた。基本的にはこの順序で質問を 行ったが, 患児の回答によっては質問の順序を入れ替 えたり，より深く尋ねたりする場合があった．質問項 目設定の根拠として, 患児の疾患に関する基礎的な知 識を明らかにするために, 「心臓の欠陥」,「病名」を 取り上げた. また児童期以降は, 親元を離れて生活す る時間が増えるため, 自分でセルフケアを行う必要 があると同時に, 幼い頃からセルフケアを行うことは 将来的な自立につながると考え,「運動制限」,「薬」, 「感染性心内膜炎の予防」を取り上げた. また, 幼い 頃から定期的な受診の必要性を理解することは, 成人 科への移行を促すと考え,「受診の理由」,「次回の受 診日」を取り上げた.

分析方法 各面接から得られた内容を基に, 逐語録を 作成した.「病状」の理解, 「セルフケア」の理解に関 する発話を抽出した. 患児の「年齢」や疾患の「重症 度」によって, 疾患理解に特徴があるのかを比較する ために Fisher の直接確率検定を行った。

倫理的配慮 面接前に書面 (小学校低学年用, 小学校 高学年用, 中学生用, 親用と発達段階に応じて 4 種類 作成した）を用いて, 患児と親に「研究の趣旨」,「調 査への参加は自由意志であり, いつでも拒否できるこ と」, 「拒否しても, 今後の医療行為における不利益は 被らないこと」,「得られた情報は個人が特定されるこ となく, プライバシーの保護に十分配慮されること」 を説明した，また，主治医から患児の疾患に関する情 報を得る可能性も説明し, 許可を得た. 受諾を得られ た場合は，患児と親の両方から同意書に署名をもらっ た（患児が自分で氏名を書けない場合は, 親が代筆し た)。面接はプライバシーが確保できる個室で行った.

\section{結 果}

患児の回答の真否は，患児に疾患説明を行っている 内科の主治医に確認し, 正しい回答をした患児を「疾 患理解している」とした. また, 性別による疾患理 解の特徴を検討するために, Fisher の直接確率検定を
行った結果, 全ての項目において性差は認められな かったため, 分析は性別を考慮せずに行うこととし た.

\section{「病状」の理解}

心臓の欠陥「わからない」, 無答などの「自分が心臓 病であることを理解していない」回答と,「心臓病」, 「心臓に穴が空いている」などの「自分が心臓病であ ることを理解している」回答に分類した.

小学校低学年では 4 名 $(50.0 \%)$, 小学校高学年で は 5 名 $(83.3 \%)$, 中学生では 12 名 $(85.7 \%)$ が心臓 病であることを理解していた，直接確率検定を行った 結果, 人数の偏りは有意ではなかった.

軽度では 14 名 $(93.3 \%)$, 中等度では 7 名 (53.8\%) が心臓病であることを理解していた。直接確率検定を 行った結果, 人数の偏りは有意であった（直接確率検 定法, $p=.029)$. 残差分析によると, 軽度では心臟病 であることを理解している患児が多く, 中等度では心 蔵病であることを理解している患児が少なかった。

また，軽度と中等度では回答の内容に差が見られた (Table 2). 軽度の患児は「心臓に穴が空いていた」, 「弁が逆流して血が少し混ざる」など，心臓の欠陥を 具体的に理解している患児が多かった。一方，中等度 の患児は「心臓病っていうのはわかるけど, 詳しいこ とはわからない」など, 心臓病であること以外は理解 していない患児が多かった。

病名「先天性心疾患」,「わからない」, 無答などの 「病名を知らない」回答と,「心室中隔欠損」などの 「病名を知っている」回答に分類した.

小学校低学年では 0 名 $(0.0 \%)$, 小学校高学年では 1 名 (16.7\%), 中学生では 6名 (42.9\%) が病名を 知っていた. 直接確率検定を行った結果, 人数の偏り は有意な傾向であった（直接確率検定法, $p=.075$ ). 残差分析によると, 小学校低学年では病名を知ってい る患児が少なく, 小学校高学年では回答に偏りは見ら れず, 中学生では病名を知っている患児が多い傾向で あった。

軽度では 3 名 $(20.0 \%)$, 中等度では 4 名 $(30.8 \%)$ が病名を知っていた。直接確率検定を行った結果, 人 数の偏りは有意ではなかった.

\section{「セルフケア」の理解}

運動制限「わからない,「特に何も気をつけていな い」などの「体育の時に気をつけていることがない」 回答と，「無理をしない」、「見学する」などの「体育 の時に気をつけていることがある」回答に分類した. 
小学校低学年では 2 名 $(25.0 \%)$, 小学校高学年で は2 名 $(33.3 \%)$, 中学生では 5 名 $(35.7 \%)$ が体育 の時に気をつけていることがあった。直接確率検定を 行った結果, 人数の偏りは有意ではなかった.

軽度では 3 名 (20.0\%), 中等度では 6 名 $(46.2 \%)$ が, 体育の時に気をつけていることがあった. 直接確 率検定を行った結果, 人数の偏りは有意ではなかっ た.

しかし, 軽度と中等度では回答の内容に差が見ら れた（Table 3). 軽度の患児は, 主治医から運動制限 は受けていないが,「(心臓が) 痛くなったら見学す
る」「「運動するとたまに心蔵が痛くなるので, こまめ に休憩している」などのように, 自分の体調を考慮し ながら疲れた時に休鄎をしていた。一方，中等度の患 児は「鉄棒の時は見学する」，「走るやつ（競技）のと きは，先生が『歩いてやって』って言う」，「あまり走 らなくてもできそうな競技は参加している」などのよ うに，主治医から制限されている競技の時は授業を見 学し, 自分ができる範囲で参加していた。

薬（管理の主体・頻度・効果・名称） 薬に関する回 答を Table 4 に示す. 薬の管理の主体は, 小学生では 4 名中 2 名が「親」と回答し, 残りの 2 名が「自分と

Table 2 Cardiac defect

\begin{tabular}{|c|c|c|}
\hline Severity & Grade & Answer \\
\hline \multirow[b]{3}{*}{ Simple } & $1-3$ & $\begin{array}{l}\text { There was a hole in my heart.* } \\
\text { I have heart disease. }\end{array}$ \\
\hline & $4-6$ & $\begin{array}{l}\text { Before surgery, there was a hole in my heart. } \\
\text { There was a congenital defect in the form of a hole in my heart, and I underwent surgery at the age of } 4-5 \text { years. } \\
\text { There was a transposition of the blood vessels. }\end{array}$ \\
\hline & $7-9$ & $\begin{array}{l}\text { There was a hole in my heart. When I exercise vigorously, my heart beats faster.* } \\
\text { I have heart disease. } \\
\text { There is a hole in the left ventricle.* } \\
\text { The hole is relatively small.* } \\
\text { There was a hole in my heart.* } \\
\text { There was a hole in my heart.* } \\
\text { I have heart disease. } \\
\text { The blood flows backwards.* } \\
\text { The tricuspid valve had only two leaflets.* }\end{array}$ \\
\hline \multirow{3}{*}{ Moderate } & $1-3$ & $\begin{array}{l}\text { (Point to the heart) Instead of two, there is only half one. } \\
\text { My heart doesn't move very much. } \\
\text { Because my heart is bad, a pacemaker was implanted. }\end{array}$ \\
\hline & $4-6$ & $\begin{array}{l}\text { I have heart disease. } \\
\text { I underwent surgery to open a constricted blood vessel.* }\end{array}$ \\
\hline & $7-9$ & $\begin{array}{l}\text { I have heart disease, but I don't know the details. } \\
\text { I have heart disease, but I don't know the details. } \\
\text { Single ventricle.* }\end{array}$ \\
\hline
\end{tabular}

${ }^{*}$ Answer was clear and correct.

Table 3 Limitation of exercise

\begin{tabular}{|c|c|c|}
\hline Severity & Grade & Answer \\
\hline \multirow[b]{2}{*}{ Simple } & $4-6$ & I take a break only if I experience heart pain. \\
\hline & $7-9$ & $\begin{array}{l}\text { I take a break if I experience heart pain. } \\
\text { I take a break frequently when it is time to participate in soccer. }\end{array}$ \\
\hline \multirow{3}{*}{ Moderate } & $1-3$ & $\begin{array}{l}\text { I don't use the horizontal bar. I only watch other kids use it. } \\
\text { I don't exercise often. }\end{array}$ \\
\hline & $4-6$ & Instead of running, I walk. \\
\hline & $7-9$ & $\begin{array}{l}\text { I exercise but I don't run. } \\
\text { I observe other kids instead of to participating in horizontal bar exercises. } \\
\text { I don't overexert. }\end{array}$ \\
\hline
\end{tabular}


Table 4 Medication

\begin{tabular}{|c|c|c|c|c|}
\hline \multirow{2}{*}{ Grade } & \multicolumn{4}{|c|}{ Answer } \\
\hline & Management & Frequency & Effect & Medication name \\
\hline \multirow{3}{*}{$1-3$} & Patient and parent. & Once per day. & Prevention of blood coagulation. & I don't know. \\
\hline & Parent. & Once in the morning. & I don't know. & I don't know. \\
\hline & Parent. & Morning, noon, and night. & Medication for heart disease. & Aldactone and warfarin. \\
\hline $4-6$ & Patient and parent. & Morning and night. & Medication for heart disease. & I don't know. \\
\hline \multirow{3}{*}{$7-9$} & Patient. & $\begin{array}{l}\text { Three times a day. } \\
\text { Morning. }\end{array}$ & $\begin{array}{l}\text { Blood. } \\
\text { It prevents blood coagulation. }\end{array}$ & $\begin{array}{l}\text { Warfarin. } \\
\text { Warfarin }\end{array}$ \\
\hline & Patient. & Morning and night. & I don't know. & Renivace. \\
\hline & & Morning and night. & It passes in the urine well. & Aldactone. \\
\hline
\end{tabular}

親」と回答した. 中学生の患児は 2 名共「自分」と 回答した. 中学生の患児は,「ホチキスで止めてあっ て，自分で出す」と工夫しながら薬の管理を行ってい た. 薬の服用の頻度は, 「1日 1 回飲む」,「朝と夜に 飲む」など，薬を服用している6 名全ての患児が知っ ていた. 薬の効果は, 6 名中 5 名が心臓病のために服 薬していることを理解して抢り，「血が固まらないよ うにする」,「尿をよく出す」など, 詳しい効果を理解 している患児は 3 名いた. 薬の名称は, 小学生では 4 名中 1 名が知っており, 中学生では 2 名共知っていた.

感染性心内膜炎の予防 感染性心内膜炎の予防につい て, 小学生で理解している患児は一人もいなかった。 中学生では, 14 名中 2 名が「歯が悪くなると心臓の 病気が悪化するかもしれないから, 虫歯になってはい けない」と, 感染性心内膜炎と歯科衛生との関連を一 部正しく理解していた.

受診の理由「わからない」, 無答などの「受診の理由 を理解していない」回答と,「心蔵の検査」,「1 年に 1 回の検診」などの「受診の理由を理解している」回 答に分類した.

小学校低学年では 3 名 $(37.5 \%)$, 小学校高学年で は 5 名 $(83.3 \%)$, 中学生では 13 名 (92.9\%) が受 診の理由を理解していた。直接確率検定を行った結 果, 人数の偏りは有意であった（直接確率検定法, $p=.009)$. 残差分析によると, 小学校低学年では受診 の理由を理解している患児が少なく, 小学校高学年で は回答に偏りは見られず，中学生では受診の理由を理 解している患児が多かった。

また, 小学校低学年と中学生では回答の内容に差が みられた（Table 5)。小学校低学年の患児は「心臓と か（医師に）見せるため」などと回答していた。一 方，中学生の患児は「どれくらい穴がふさがっている かの確認」「前に手術をしたので，定期的な検査でき た」などと回答していた．中学生の患児では「定期的」
に受診することを理解している患児が 3 名いた.

軽度では 12 名 $(80.0 \%)$, 中等度では 9 名 $(69.2 \%)$ が受診の理由を理解していた。直接確率検定を行った 結果, 人数の偏りは有意ではなかった.

次回の受診日「わからない,，無答などの「次回の受 診日を知らない」回答と, 「1 年に 1 回」,「冬休み」, 「来年の 8 月 5 日」などの「次回の受診日を知ってい る」回答に分類した.

小学校低学年では 3 名 $(37.5 \%)$, 小学校高学年で は3 名 $(50.0 \%)$, 中学生では 13 名 (92.9\%) が次 回の受診日を知っていた。直接確率検定を行った結 果, 人数の偏りは有意であった（直接確率検定法, $p=.013)$. 残差分析によると, 小学校低学年では次回 の受診日を知っている患児が少なく，小学校高学年で は回答に偏りは見られず，中学生では次回の受診日を 知っている患児が多かった。

軽度では 12 名 $(80.0 \%)$, 中等度では 7 名 $(53.8 \%)$ が次回の受診日を知っていた。直接確率検定を行った 結果, 人数の偏りは有意ではなかった.

\section{考察}

\section{患児の「年齢」，疾患の「重症度」による差が見られ なかった疾患理解}

運動制限, 感染性心内膜炎の予防, 薬の頻度, 薬の 効果の理解は, 患児の「年齢」や疾患の「重症度」に よる差が見られなかった。

運動制限で，患児の「年齢」による差が見られな かったのは，体育が始まる小学生以降は，年齢に関わ らず，医療者や親，教師が患児に体調を考慮しながら 運動を行うように指導しているためであろう。疾患 の「重症度」による差が見られなかったのは, 幼い頃 から運動制限がある患児にとって, 運動制限を特別な ことと意識していなかったためであることが考えられ 
Table 5 Reason for consultation

\begin{tabular}{|c|c|c|}
\hline Severity & Grade & Answer \\
\hline \multirow[b]{3}{*}{ Simple } & $1-3$ & For an examination. \\
\hline & $4-6$ & $\begin{array}{l}\text { For a medical examination. } \\
\text { Cardiac examination. } \\
\text { To identify abnormalities. }\end{array}$ \\
\hline & $7-9$ & $\begin{array}{l}\text { To confirm how long a hole of the heart is occupied and determine whether there are any abnormalities. } \\
\text { To determine whether the disease worsened or improved. } \\
\text { Cardiac examination. } \\
\text { Periodic postoperative follow-up exam. } \\
\text { Cardiac examination. } \\
\text { Examination. } \\
\text { Examination of heart sounds and murmurs. } \\
\text { Annual medical examination. }\end{array}$ \\
\hline \multirow[b]{3}{*}{ Moderate } & $1-3$ & $\begin{array}{l}\text { Cardiac examination. } \\
\text { Cardiac examination. }\end{array}$ \\
\hline & $4-6$ & $\begin{array}{l}\text { Cardiac treatment. } \\
\text { Examination. }\end{array}$ \\
\hline & $7-9$ & $\begin{array}{l}\text { Cardiac examination. } \\
\text { Cardiac examination. } \\
\text { Periodic medical examination. } \\
\text { Medical examination. } \\
\text { Assessment of current condition. }\end{array}$ \\
\hline
\end{tabular}

る. また, 伊庭 ${ }^{9)}$ の結果と異なり, 本研究でセルフ ケアの必要性を理解していても, 無理して運動を続け てしまう患児はいなかった。本研究の患児は, 教師や 友人に疾患のことを理解してもらっており，体育の時 に見学しやすい環境を作ることができていると考えら れるだろう。

薬の頻度は，全ての患児が理解していた。これは， 自分が体験しているセルフケアは, 小学校低学年で も理解できるという伊庭 ${ }^{9)}$ の結果と一致する。また 薬の効果は, 6 名中 5 名が心蔵病のための薬であるこ と, そのうち 3 名が「血液をさらさらにする」などの より詳しい効果を理解していた. 薬の服用は家庭で行 うセルフケアであるため, 親の説明が患児の理解に影 響していると考えられる. 患児の服用している薬の効 果を知っている親は $44.6 \%$, 薬の副作用を知ってい る親はわずか $7.1 \%$ であり，親の薬に関する理解は決 して十分とは言えない ${ }^{4)}$. しかし, 親が患児の薬につ いてよく理解し, 患児に説明を行っていると, 小学校 低学年でも薬の詳しい効果を理解できるのだろう。

感染性心内膜炎の予防は, 28 名中 2 名しか理解 していなかった。この結果は, 成人期の患者であっ

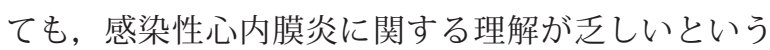
Moons ${ }^{19)}$ らの結果とも一致する。その理由として, 感染性心内膜炎の原理の理解の欠如が考えられる.
「歯科治療中の流血に伴って体内に入った細菌が，血 液と共に心臓まで流れて，心蔵で炎症を起こす」とい う感染性心内膜炎の原理は，「血液が養分を全身に運 ぶ」ことを学習する小学 6 年生であれば理解できる. 今後は, まず感染性心内膜炎の原理を説明した後, 歯 科衛生などの予防法について説明することが望ましい だろう。

\section{患児の「年齢」による差が見られた疾患理解}

病名, 受診の理由, 次回の受診日は, 中学生が小学 校低学年よりも, 薬の名称は, 中学生が小学生よりも 良く理解していた。薬の管理の主体は, 親（小学生） から患児 (中学生) に移行していた。

病名の理解で，患児の「年齢」による差が見られた のは, 中学生になると「心室」や「弁」などの解剖用 語を理解できるようになるためであることが考えられ る.しかし, 小学校高学年の患児が病名を知っていた ことから, 患児が疾患に興味を持つことは, 疾患理解 を促進させることがわかる。また，小学校高学年に なると，様々な知識を体系づけて考えられるようにな る ${ }^{15)}$ ため, 自分の疾患と病名を関連づけて考えるこ とができるようになるのだろう。

受診の理由, 次回の受診日の理解で, 患児の「年齢」 による差が見られたのは, 中学生になると, 先を見通 
して疾患と付き合うことが理解できるようになるため であることが考えられる. 小学校高学年では $83 \%$, 中学生では $93 \%$ の患児が受診の理由を理解していた ことから, 患児は心疾患のためであることを理解し ながら受診していることが伺える，また，中学生の 93\%が次回の受診日を知っていたことから，患児は 定期的に受診する必要性も理解していると言える。軽 度の患児の中には, 将来的には受診が必要のない患児 もいる ${ }^{3)}$ が，小児期は軽度であっても定期的な受診 が必要であるため, 疾患の「重症度」による差は見ら れなかったのだろう。

薬の管理の主体が，中学生を境に親から患児へと移 行していたのは, この時期の発達的な特徴である, 自 分の身体を自分で守ろうとする傾向 ${ }^{10)}$ の現れである と考えられる．また，患児が薬を管理するのに伴っ て，どの薬があといくつ残っているのかなどを気にか けるようになるため, 中学生になると薬の名称も知っ ていたのであろう.

\section{疾患の「重症度」による差が見られた疾患理解}

心蔵の欠陥は, 軽度の患児が中等度の患児よりも具

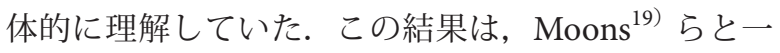
致しており, 軽度の疾患は解剖学的な構造が単純で, 患児にとって言葉で説明がしやすかったことが理由と して考えられる.

\section{発達段階を考慮した疾患説明}

心臓を学習する前の小学校低学年の患児であって も, 心臓を認識している。.また，身体を動かすと疲労 を感じたり, 毎日薬を服用したりする経験から, 自分 が心疾患であることを自覚している. そのため, この 時期は患児の生活や経験に絡めながら，「胸が苦しく なったら先生やお母さんに教えてね」,「病気を治して いる途中だから，○○の運動はやってもいいけど， $\triangle$ の運動はやめようね」などと，セルフケアの必要性 を説明することが効果的である. 幼い頃から, 大人が 患児の行動を一方的に制限するのではなく, 患児が主 体となって疾患を抱える自分の行動を考えることがで きるように, この時期から「セルフケアの大切さ」を 伝えていく必要があると考える. また小学校高学年に なると，説明や本などの間接経験を通して学習するこ とや，様々な情報を体系づけることが可能になるた め, これまでの患児の経験と疾患説明で得た知識が関 連づけられるように説明すると良いだろう。

また心臓を学習する小学 6 年生以降の患児は, 目 に見えない心臓の構造も理解することが可能になるた
め, 解剖図を用いて視覚的にわかりやすく, 疾患や心 内膜炎の原理を説明することが重要である.

\section{研究の限界と今後の課題}

本研究では, 小, 中学生の患児の疾患理解の程度は 明らかになったが，この時期の患児が適切なセルフケ アを行う上で，十分なものであるのかどうかまでは判 断することができなかった。 今後, 患児が適切なセル フケアを行う上での十分な疾患理解の程度 (基準) が 明らかになれば，医療者が疾患説明を行う際の手がか りになるだろう。また，本研究で明らかになった 10 項目の疾患理解は, 疾患理解の一部に過ぎない。 今後 は, 疾患理解において重要な「手術」や「治療」に関 する理解も明らかにする必要があるだろう.

また調査時期が，夏休み期間中であったことから， 軽度の患児が多く, 重度の患児が少なかった。 また, 中等度の中学生の患児は, 夏休みを避けて受診するこ とから，各重症度の平均年齢に差があったことも疾患 理解に影響を与えていると考えられる. 今後は，重度 の患児の疾患理解も調查すると同時に, 各重症度の平 均年齢を統制することによって, 先天性心疾患患児の 疾患理解をより広い視野で明らかにする必要がある.

\section{結 論}

本研究では, 小, 中学生の患児は, 自分が心臓病で あることや定期的な受診の必要性，薬の服用，運動制 限について理解していることが明らかになった。運動 制限, 薬の頻度・効果, 感染性心内膜炎の予防の理解 は，患児の「年齢」や疾患の「重症度」による差が見 られなかった. しかし, 病名, 薬の名称, 受診の理 由, 次回の受診日の理解では, 患児の「年齢」による 差が見られ，年齢が上がると共に，理解している患児 が増加し，薬の管理の主体は「親」から「患児」へと 移行していた。藏の欠陥の理解では，疾患の「重症 度」による差が見られ，軽度の患児の方が具体的に理 解していた．医療者は，患児に疾患説明を行う際，認 知的な発達段階や疾患の構造の複雑さを考慮すること が重要である.

\section{引用文献}

1) 循環器病の診断と治療に関するガイドライン（2010 年度 合同研究班報告). 成人先天性心疾患診療ガイドライン （2011 年改訂版） 2011 
2) Somerville J: Management of adults with congenital heart disease: An increasing problem. Annu Rev Med 1997; 48: 283-293

3) Mackie AS, Ionescu-Ittu R, Therrien J, et al: Children and adults with congenital heart disease lost to follow-up? Who and when? Circulation 2009; 120: 302-309

4) Cheuk DK, Wong SM, Choi YP, et al: Parents' understanding of their child's congenital heart disease. Heart 2004; 90: 435-439

5) Clarizia NA, Chahal N, Manlhiot C, et al: Transition to adult health care for adolescents and young adults with congenital heart disease: Perspectives of the patient, parent and health care provider. Can J Cardiol 2009; 25: 317-322

6) Cetta F, Warnes CA: Adults with congenital heart disease: Patient knowledge of endocarditis prophylaxis. Mayo Clin Proc 1995; 70: 50-54

7) Van Deyk K, Pelgrims E, Troost E, et al: Adolescents' understanding of their congenital heart disease on transfer to adult-focused care. Am J Cardiol 2010; 106: 1803-1807

8) Wang Q, Hay M, Clarke D, et al: Adolescents' drawings of their cardiac abnormality. Cardiol Young 2011; 21: 556-561

9）伊庭久江：先天性心疾患をもつ幼児・学童の “自分の疾 患のとらえ方’。千葉看会誌 2005; 11: 38-45

10）仁尾かおり, 藤原千惠子 : 先天性心疾患をもつ思春期の 子どもの病気認知. 小児保健研究 2003; 62: 544-551

11）青木雅子：先天性心疾患の子どものボディイメージの構
成要素一社会で生活する青年たちの語りから一，日小児 看護会誌 $2005 ; 14: 16-22$

12) Salter M. (前川厚子訳). 子供のボディ・イメージの発 達と変化. ボディ・イメージと看護. 東京, 医学書院, 1992

13） Piaget J. (波多野完治, 滝沢武久訳). 知能の心理学. 東 京，みすず書房，1967

14）上田礼子：生涯人間発達学. 東京, 三輪書店, 1996

15）岩田純一，佐々木正人，石田勢津子，ほか：児童の心理 学—ベーシック現代心理学 3-. 東京, 有斐閣, 1995, pp. 2-31

16）高田利武：他者と比べる自分一社会的比較の心理学一. 東京, サイエンス社, 2011

17） Goswami U.（岩男卓実・上淵 寿・古池若葉・富山尚 子・中島伸子訳). 子どもの認知発達. 東京, 新曜社, 2003

18）落合良行, 伊藤裕子, 齊藤誠一：青年の心理学—ベーシッ ク現代心理学 4 (改訂版) 一. 東京, 有斐閣, 2002, pp. 25-48

19) Moons P, De Volder E, Budts W, et al: What do adult patients with congenital heart disease know about their disease, treatment, and prevention of complications? A call for structured patient education. Heart 2001; 86: 74-80

20) Adult Congenital Heart Association: 32nd Bethesda Conference: "Care of the adult with congenital heart disease." J Am Coll Cardiol 2001; 37: 1161-1198 